\title{
Cloning, sequence analysis, expression and inactivation of the Corynebacterium glutamicum pta-ack operon encoding phosphotransacetylase and acetate kinase
}

\author{
Dieter J. Reinscheid, ${ }^{1}$ Stephanie Schnicke, ${ }^{1}$ Doris Rittmann, ${ }^{2}$ \\ Ulrike Zahnow, ${ }^{2}$ Hermann Sahm ${ }^{2}$ and Bernhard J. Eikmanns ${ }^{1}$
}

Author for correspondence: Bernhard J. Eikmanns. Tel: +4973150 22707. Fax : +497315022719.
e-mail : bernhard.eikmanns@ biologie.uni-ulm.de

1 Abteilung Angewandte Mikrobiologie, Universităt Ulm, D-89069 Ulm,

Germany

2 Institut für Biotechnologie, Forschungszentrum Jülich, D-52425 Jülich, Germany

\begin{abstract}
The Corynebacterium glutamicum ack and pta genes encoding the acetateactivating enzymes acetate kinase and phosphotransacetylase were isolated, subcloned on a plasmid and re-introduced into Corynebacterium glutamicum. Relative to the wild-type, the recombinant strains showed about tenfold higher specific activities of both enzymes. Sequence analysis of a 3657 bp DNA fragment revealed that the ack and pta genes are contiguous in the corynebacterial chromosome, with pta upstream and the last nucleotide of the pta stop codon (TAA) overlapping the first of the ack start codon (ATG). The predicted gene product of pta consists of 329 amino acids $\left(M_{r} 35242\right)$, that of ack consists of 397 amino acids $\left(M_{r} 43098\right)$ and the amino acid sequences of the two polypeptides show up to $60 \%$ (phosphotransacetylase) and $53 \%$ (acetate kinase) identity in comparison with respective enzymes from other organisms. Northern (RNA) blot hybridizations using pta- and ack-specific probes and transcriptional cat fusion experiments revealed that the two genes are transcribed as a $2.5 \mathrm{~kb}$ bicistronic mRNA and that the expression of this operon is induced when Corynebacterium glutamicum grows on acetate instead of glucose as a carbon source. Directed inactivation of the chromosomal pta and ack genes led to the absence of detectable phosphotransacetylase and acetate kinase activity in the respective mutants and to their inability to grow on acetate. These data indicate that no isoenzymes of acetate kinase and phosphotransacetylase are present in Corynebacterium glutamicum and that a functional acetate kinase/phosphotransacetylase pathway is essential for growth of this organism on acetate.
\end{abstract}

Keywords: Corynebacterium glutamicum, acetate metabolism, acetate kinase, phosphotransacetylase, $p t a-a c k$ operon

\section{INTRODUCTION}

Corynebacterium glutamicum and its subspecies are widely used for large-scale amino acid production (Leuchtenberger, 1996). This organism grows aerobically on glucose and on acetate as the sole carbon sources and both can also serve as substrates for the production of glutamate, lysine and threonine (reviewed by Kinoshita \& Tanaka, 1972). Growth on, and amino

The EMBL/GenBank/DDBJ accession number for the sequence reported in this paper is $X 89084$. acid production from, acetate as the sole carbon source requires the uptake of acetate, its activation to acetylCoA and the operation of the glyoxylate shunt as an anaplerotic sequence (Clark \& Cronan, 1996). Key enzymes of acetate metabolism in Corynebacterium glutamicum are acetate kinase, phosphotransacetylase and the glyoxylate-cycle enzymes isocitrate lyase and malate synthase (Ozaki \& Shiio, 1969; Shiio et al., 1969). Acetate kinase activates acetate to acetyl phosphate, which is subsequently converted to acetyl-CoA by phosphotransacetylase. Isocitrate lyase catalyses the cleavage of isocitrate to succinate and glyoxylate, and malate synthase condenses glyoxylate with acetyl-CoA 
to give malate. The latter enzymes are required to bypass the decarboxylation steps of the tricarboxylic acid cycle (Kornberg, 1966). Whereas not much is known about the acetate-activating enzymes of Corynebacterium glutamicum, the isocitrate lyase and malate synthase of this organism have been the subjects of intensive investigation. Both enzymes were purified and biochemically characterized and it turned out that their activities are controlled by allosteric regulation by a variety of intermediates of central metabolism (Reinscheid et al., 1994a, b). Isolation and analysis of the Corynebacterium glutamicum genes encoding isocitrate lyase and malate synthase (ace $A$ and $a c e B$ ) revealed that the genes are clustered on the chromosome and oriented in opposite directions (Reinscheid et al., 1994a, b). Further studies showed that the expression of ace $A$ and $a c e B$ is regulated at the transcriptional level, resulting in high and low specific activities of both enzymes in the presence and absence, respectively, of acetate in the growth medium (Wendisch et al., 1997). Acetate kinase and phosphotransacetylase of Corynebacterium glutamicum also show higher specific activities upon growth in the presence of acetate (Wendisch et al., 1997). However, so far the basis for the different acetate kinase and phosphotransacetylase activities has not been investigated and it remains unclear whether the observed regulation is also due to transcriptional control of the respective genes.

To understand the molecular basis for acetate activation and its regulation in Corynebacterium glutamicum, we initiated studies on both the acetate kinase and the phosphotransacetylase of this organism. We describe the biochemical characterization of acetate kinase and phosphotransacetylase in extracts of Corynebacterium glutamicum, the isolation and analysis of the respective genes $a c k$ and $p t a$, and we show data on the expression and regulation of the two genes under different growth conditions. Finally, we present data on the construction and characterization of defined $a c k$ and $p t a$ mutants of Corynebacterium glutamicum.

\section{METHODS}

Bacteria, plasmids and culture conditions. The bacterial strains and plasmids, their relevant characteristics and their sources are given in Table 1 . The minimal medium used for Corynebacterium glutamicum has been described previously (Eikmanns et al., 1991b) and contained 4\% (w/v) glucose or $2 \%(\mathrm{w} / \mathrm{v})$ potassium acetate. M9 medium (Sambrook et al., 1989) containing $0.5 \%(\mathrm{w} / \mathrm{v})$ glucose or $0.4 \%(\mathrm{w} / \mathrm{v})$ potassium acetate was used as a minimal medium for Escherichia coli and LB medium (Sambrook et al., 1989) was used as the complex medium for both organisms. For the growth of $E$. coli JRG1061, $2 \mathrm{mM}$ tryptophan was added. When appropriate, ampicillin $\left(100 \mu \mathrm{g} \mathrm{ml}^{-1}\right)$ or kanamycin $\left(50 \mu \mathrm{g} \mathrm{ml}^{-1}\right)$ was added to the medium. Corynebacterium glutamicum was grown aerobically at $30^{\circ} \mathrm{C}, \mathrm{E}$. coli at $37^{\circ} \mathrm{C}$.

DNA preparation, transformation and conjugation. The isolation of chromosomal DNA from Corynebacterium glutamicum, the isolation of plasmids from E. coli and Corynebacterium glutamicum and the transformation of both organisms were performed as previously described (Eikmanns et al., 1994). The conjugation between E. coli S17-1 and Corynebacterium glutamicum was performed as described by Schäfer et al. (1990), and transconjugants were selected on LB agar plates containing kanamycin $\left(25 \mu \mathrm{g} \mathrm{ml}^{-1}\right)$ and nalidixic acid $\left(50 \mu \mathrm{g} \mathrm{ml}^{-1}\right)$.

DNA manipulations. Restriction enzymes, T4 DNA ligase, Klenow polymerase, calf intestine phosphatase, proteinase $\mathrm{K}$, DNase I, RNase A, T7 RNA polymerase and RNasin were obtained from Boehringer Mannheim and used as instructed by the manufacturer. Restriction-generated fragments were separated on $0.8 \%$ agarose gels and isolated and purified by using the Qiaex II Gel Extraction Kit from Qiagen.

DNA hybridization experiments were performed as previously described (Reinscheid et al., 1994a). The $1.4 \mathrm{~kb}$ ClaI fragment isolated from pJU2 was labelled with digoxigenin-dUTP and used as a probe. Labelling, hybridization, washing and detection was performed using the non-radioactive DNA Labelling and Detection $\mathrm{Kit}$ and the instructions from Boehringer Mannheim.

For sequencing, the $3.3 \mathrm{~kb} \mathrm{XbaI-BamHI}$ fragment from pJU2 was ligated into pUC18 and, after restriction with either $S p b \mathrm{I} / \mathrm{Xbal}$ or $\mathrm{BamHI} / \mathrm{SacI}$, progressive unidirectional deletions of the inserted DNA were created with the Erase-a-Base System from Promega. Appropriate subclones were sequenced using the AutoRead Sequencing Kit from Pharmacia with subsequent electrophoretic analysis with an ALF DNA sequencer from Pharmacia. The nucleotide sequence containing the terminator structure was determined using $\mathrm{pJU2}$, appropriate primers and the AutoRead Sequencing Kit from Pharmacia. Sequence data were compiled and analysed with the HUSAR program package from EMBL.

RNA isolation and Northern hybridization. Total RNA from Corynebacterium glutamicum was isolated as described by Börmann et al. (1992). For hybridization, aliquots of the RNA were separated on an agarose gel containing $17 \%(\mathrm{v} / \mathrm{v})$ formaldehyde and transferred onto a nylon membrane (Eikmanns et al., 1994). The pta- and ack-specific antisense RNA probes were prepared by ligating the $0.49 \mathrm{~kb}$ EcoRI-Sall pta fragment into pGEM-4Z and the $0.33 \mathrm{~kb}$ HindIII-KpnI ack fragment into pGEM-3Z, linearizing the resulting plasmids with HindIII and EcoRI, respectively, and synthesizing digoxigenin-dUTP-labelled RNAs using T7 RNA polymerase and the RNA Labelling Kit from Boehringer Mannheim. Hybridization (at $46^{\circ} \mathrm{C}$, in the presence of $50 \%$ formamide), washing and detection was performed with the "Nucleic Acid Detection Kit' from Boehringer Mannheim.

Construction of cat fusions. The promoter probe vector $\mathrm{pEKplCm}$ was used for construction of a transcriptional fusion of the pta-ack promoter region to the cat (chloramphenicol acetyltransferase) gene. The fusion was generated by insertion of the blunt-ended $1.26 \mathrm{~kb} \mathrm{XbaI-EcoRI} \mathrm{fragment}$ (see Fig. 1) into pEKplCm restricted with Sall and blunt-ended by treatment with Klenow polymerase. The orientation of the insert was determined by restriction mapping. The copy number of the $\mathrm{pEKplCm}$ derivative was determined by the method described by Nesvera et al. (1997) and found to be comparable to the original vector, thus ruling out major errors in evaluation of the promoter activity caused by different cat gene dosage.

Gene disruption. The chromosomal pta and ack genes were disrupted by a method described by Schwarzer \& Pühler (1991). A pta-internal $0.5 \mathrm{~kb}$ EcoRI-Sall fragment and a $0.33 \mathrm{~kb}$ ack-internal HindIII-KpnI fragment from pJU2 were ligated into the mobilizable $E$. coli vector pEM1, which is nonreplicative in Corynebacterium glutamicum. The resulting 
Table 1. Bacterial strains and plasmids used in this study

\begin{tabular}{|c|c|c|}
\hline Strain/plasmid & Relevant characteristics & Source/reference \\
\hline \multicolumn{3}{|l|}{ Strains } \\
\hline \multicolumn{3}{|l|}{ E. coli } \\
\hline DH5 $\alpha$ & supE44, hsdR17, recA1, endA1, gyrA96, thi-1, relA1 & Hanahan (1985) \\
\hline JRG1061* & ack-11, $\operatorname{trp} A 9761, \operatorname{trp} R 72, i c l R 7$, gal-25, $\lambda^{-}$ & Guest (1979) \\
\hline S17-1 & Mobilizing donor strain & Simon et al. (1983) \\
\hline \multicolumn{3}{|l|}{ C. glutamicum } \\
\hline WT & Wild-type strain ATCC 13032 & $\begin{array}{l}\text { American Type Culture } \\
\text { Collection }\end{array}$ \\
\hline $13 \mathrm{AK}$ & Fluoroacetate-resistant mutant of strain WT, acetate kinase negative & Wendisch et al. (1997) \\
\hline 13PTA & $\begin{array}{l}\text { Fluoroacetate-resistant mutant of strain WT, phosphotransacetylase } \\
\text { negative }\end{array}$ & Wendisch et al. (1997) \\
\hline 13AK-PTA & $\begin{array}{l}\text { Fluoroacetate-resistant mutant of strain WT, acetate kinase and } \\
\text { phosphotransacetylase negative }\end{array}$ & Wendisch et al. (1997) \\
\hline \multicolumn{3}{|l|}{ Cosmids/plasmids } \\
\hline pHC79-based gene library & C. glutamicum WT chromosomal DNA cloned in cosmid pHC79 & Börmann et al. (1992) \\
\hline $\mathrm{pHC} 3 \mathrm{a}$ & recombinant pHC79 cosmid able to complement $E$. coli JRG1061 & This work \\
\hline $\mathrm{pJC1}$ & E. coli-C. glutamicum shuttle vector, $\mathrm{Ap}^{\mathrm{R}} \mathrm{Km}^{\mathrm{R}}$ & Cremer et al. (1988) \\
\hline pJU2 & pJC1 containing $4.3 \mathrm{~kb}$ Sau3AI fragment from $\mathrm{pHC} 3 \mathrm{a}$ & This work \\
\hline pUC18 & Cloning vector, $\mathrm{Ap}^{\mathrm{R}}$ & Vieira \& Messing (1982) \\
\hline pEKplCm & Promoter probe vector carrying the promoterless cat gene, $\mathrm{Km}^{\mathrm{B}}$ & Eikmanns et al. (1991a) \\
\hline $\mathrm{pEKplCm}-\mathrm{DR} 2$ & pEKplCm containing $1255 \mathrm{bp} \mathrm{XbaI-EcoRI} \mathrm{fragment} \mathrm{from} \mathrm{pJU2}$ & This work \\
\hline pEM1 & Integration vector, ori $\mathrm{V}$ ori $\mathrm{T}, \mathrm{Km}^{\mathrm{R}}$ & Schrumpf et al. (1991) \\
\hline pGEM-3Z/pGEM-4Z & Transcription vector carrying the $T 7$ and SP6 promoters, $A p^{R}$ & Promega \\
\hline
\end{tabular}

* Kindly provided by Barbara Bachmann, E. coli Genetic Stock Center, USA.

plasmids (pEM-pta and pEM-ack) were introduced into Corynebacterium glutamicum by conjugation from $E$. coli S17-1. To prove the integration of pEM-pta and pEM-ack at the chromosomal pta-ack locus of the Corynebacterium glutamicum transconjugants IN-pta and IN-ack, we performed Southern-blot analysis with the respective mutants. EcoRI-restricted chromosomal DNA from these strains was hybridized to the labelled $1.4 \mathrm{~kb}$ Cla fragment, resulting in two signals at $2.3 \mathrm{~kb}$ and $3.8 \mathrm{~kb}$ with the DNA from strain INpta and one signal at $5.8 \mathrm{~kb}$ with the DNA from strain IN-ack. These sizes were expected from integration of pEM-pta within the $p t a$ gene locus and of pEM-ack within the ack gene locus of Corynebacterium glutamicum.

Enzyme assays. To determine enzyme activities in cell-free extracts, Corynebacterium glutamicum cells were grown in minimal medium to the exponential growth phase, washed twice in $20 \mathrm{ml} 50 \mathrm{mM}$ Tris/ $\mathrm{HCl}$ buffer, $\mathrm{pH} \mathrm{7,} \mathrm{and} \mathrm{resuspended}$ in $1 \mathrm{ml}$ of the same buffer containing $10 \mathrm{mM} \mathrm{MgCl}_{2}, 1 \mathrm{mM}$ EDTA, $1 \mathrm{mM}$ DTT (except for determination of chloramphenicol acetyltransferase activity) and $30 \%(\mathrm{w} / \mathrm{v})$ glycerol. After disruption of the cells by sonication (Eikmanns et al., 1991b) and subsequent centrifugation for $30 \mathrm{~min}$ at $13000 \mathrm{~g}$ and $4{ }^{\circ} \mathrm{C}$, the supernatant was used for the assays. The protein concentration was determined by the Biuret method (Gornall et al., 1949) using BSA as the standard.

Acetate kinase activity was analysed in the acetyl phosphate forming direction as described by van Dyk \& LaRossa (1987) in $1 \mathrm{ml} 70 \mathrm{mM}$ Tris/HCl, pH 7.6, $50 \mathrm{mM} \mathrm{MgCl}_{2}, 3 \mathrm{mM} \mathrm{ATP}$, $3 \mathrm{mM}$ phosphoenolpyruvate, $0.3 \mathrm{mM} \mathrm{NADH}, 7 \mathrm{U}$ pyruvate kinase, $10 \mathrm{U}$ lactate dehydrogenase, and $340 \mathrm{mM}$ acetate as substrate. One unit of acetate kinase activity is defined as $1 \mu \mathrm{mol} \mathrm{NADH}$ consumed per min at $30^{\circ} \mathrm{C}$.
Phosphotransacetylase activity was assayed by monitoring the conversion of acetyl phosphate to acetyl-CoA according to a modified method described by Brown et al. (1977). In a final volume of $1 \mathrm{ml}$, the assay contained $100 \mathrm{mM}$ Tris $/ \mathrm{HCl}$,

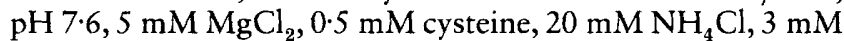
CoA and $20 \mathrm{mM}$ acetyl phosphate. The formation of acetylCoA was followed photometrically at $232 \mathrm{~nm}$. One unit of activity corresponds to $1 \mu \mathrm{mol}$ acetyl-CoA formed per min at $30^{\circ} \mathrm{C}$.

Chloramphenicol acetyltransferase activity was assayed photometrically at $412 \mathrm{~nm}$ as described by Shaw (1975) in $1 \mathrm{ml}$ $100 \mathrm{mM}$ Tris/HCl, pH 7.8, $1 \mathrm{mM}$ 5,5'-dithiobis(2-nitrobenzoic acid), $0.1 \mathrm{mM}$ acetyl-CoA and $0.25 \mathrm{mM}$ chloramphenicol. One unit of activity is defined as $1 \mu \mathrm{mol}$ chloramphenicol acetylated per min at $37^{\circ} \mathrm{C}$.

\section{RESULTS}

\section{Acetate kinase and phosphotransacetylase activities in Corynebacterium glutamicum}

The specific activities of acetate kinase and phosphotransacetylase were determined in cell-free extracts of Corynebacterium glutamicum WT grown on minimal medium containing glucose or acetate as the carbon source (Table 2). As already shown by Wendisch $e t$ al. (1997), the specific activities of both enzymes were about threefold higher in acetate-grown cells than in glucosegrown cells, confirming that the two enzymes are subject to coordinated regulation by the carbon source in the growth medium. 
The analysis of the acetate kinase activity in extracts of Corynebacterium glutamicum WT revealed apparent $K_{\mathrm{m}}$ values of $7.9 \mathrm{mM}$ for acetate and $0.23 \mathrm{mM}$ for ATP, which are both somewhat lower than those reported for acetate kinases from Methanosarcina thermophila (Aceti \& Ferry, 1988) and Clostridium acetobutylicum (Winzer et al., 1997), and are in the same range as those reported for acetate kinases from E. coli and Salmonella typhimurium (Fox \& Roseman, 1986). As for the acetate kinases from other organisms (Fox \& Roseman, 1986), the Corynebacterium glutamicum enzyme required $\mathrm{MgCl}_{2}(2 \mathrm{mM})$, which could be substituted by $\mathrm{MnCl}_{2}$ at the same concentration. The enzyme activity was inhibited by $\mathrm{CaCl}_{2}(10 \mathrm{mM}$ led to an inhibition of about $50 \%$ ) but not by $\mathrm{NaCl}$ and $\mathrm{LiCl}$ (up to $20 \mathrm{mM}$ ). The substrate specifity of the Corynebacterium glutamicum acetate kinase was tested with propionate, butyrate and succinate. The enzyme was active with propionate, although the apparent $K_{\mathrm{m}}$ was higher $(15 \mathrm{mM})$ and the apparent $V_{\max }$ was about $25 \%$ lower than with acetate. When butyrate or succinate were tested as substrates, the activity was below the detection level of $0.01 \mathrm{U}(\mathrm{mg}$ protein) ${ }^{-1}$. The Corynebacterium glutamicum enzyme was not active with GTP or ITP at concentrations similar to, or greater than, those required for saturation by ATP as has been shown for the respective enzymes from E. coli and S. typhimurium (Fox \& Roseman, 1986).

Characterization of the phosphotransacetylase activity in extracts of Corynebacterium glutamicum WT revealed apparent $K_{\mathrm{m}}$ values of $0.13 \mathrm{mM}$ for acetyl phosphate, which is about tenfold lower than that of phosphotransacetylases from most other bacteria (Shimizu et al., 1969; Lundie \& Ferry, 1989) and 0.4 mM for CoA, which is slightly higher than those reported for the phosphotransacetylase enzymes from other organisms (Shimizu et al., 1969; Rado \& Hoch, 1973; Lundie \& Ferry, 1989). As described for the Bacillus subtilis enzyme (Rado \& Hoch, 1973), the phosphotransacetylase activity in Corynebacterium glutamicum was unaffected by pyruvate, isocitrate, succinate and malate at concentrations up to $10 \mathrm{mM}$.

\section{Isolation and subcloning of the ack and pta genes from Corynebacterium glutamicum}

The Corynebacterium glutamicum ack gene, encoding acetate kinase, was isolated by heterologous complementation of E. coli mutant JRG1061 using a Corynebacterium glutamicum WT cosmid gene library based on vector pHC79. Due to its acetate kinase deficiency, strain JRG1061 is not able to grow on acetate minimal medium (Guest, 1979). Pooled recombinant cosmids were transformed into E. coli JRG1061 and, by testing about 2000 transformants for growth on acetate minimal medium, four clones were obtained which grew on acetate as the sole carbon source. After isolation of the four cosmids (pHC3, $\mathrm{pHC} 3 \mathrm{a}, \mathrm{pHC} 8$ and $\mathrm{pHC}$ ) and retransformation into $E$. coli JRG1061, the transformants again grew on acetate minimal medium, suggesting that the cosmids carried the ack gene. For subcloning purposes, cosmid pHC3a was partially digested with Sau3AI and fragments between 2 and $6 \mathrm{~kb}$ were ligated into the BamHI site of the E. coliCorynebacterium glutamicum shuttle vector $\mathrm{pJC} 1$. The ligation mixture was transformed into $E$. coli JRG1061 and transformants were again screened for growth on acetate minimal medium. By this procedure, five clones carrying plasmids able to complement the acetate kinase deficiency of E. coli JRG1061 were obtained. The

Table 2. Specific activities of acetate kinase and phosphotransacetylase in cell-free extracts of Corynebacterium glutamicum strains

The cells were grown in minimal medium (MM) containing glucose or acetate as the carbon source.

The values are means \pm SD obtained from at least three independent cultivations and two determinations per experiment. NG, No growth

\begin{tabular}{|c|c|c|c|c|}
\hline \multirow[t]{2}{*}{ Strain } & \multicolumn{2}{|c|}{ Acetate kinase activity* } & \multicolumn{2}{|c|}{ Phosphotransacetylase activity* } \\
\hline & MM+glucose & $\mathrm{MM}+$ acetate & MM+glucose & MM + acetate \\
\hline WT & $0.36 \pm 0.08$ & $0 \cdot 90 \pm 0 \cdot 11$ & $1 \cdot 28 \pm 0.08$ & $3 \cdot 14 \pm 0 \cdot 15$ \\
\hline WT/pJC1 & $0.34 \pm 0.04$ & $1.07 \pm 0.09$ & $1.36 \pm 0.08$ & $2.99 \pm 0.12$ \\
\hline $\mathrm{WT} / \mathrm{pJU} 2$ & $3 \cdot 64 \pm 0 \cdot 30$ & $8 \cdot 56 \pm 0 \cdot 45$ & $10 \cdot 14 \pm 0 \cdot 89$ & $35 \cdot 76 \pm 4 \cdot 56$ \\
\hline $13 \mathrm{AK}$ & $<\overline{0.01}$ & NG & $0.90 \pm 0.09$ & NG \\
\hline $13 \mathrm{AK} / \mathrm{pJU} 2$ & $2 \cdot 19 \pm 0 \cdot 92$ & $5.43 \pm 1 \cdot 42$ & $6 \cdot 23 \pm 0 \cdot 42$ & $19 \cdot 12 \pm 4 \cdot 01$ \\
\hline 13PTA & $0.24 \pm 0.04$ & NG & $<\overline{0} .01$ & NG \\
\hline 13PTA/pJU2 & $2 \cdot 25 \pm 0 \cdot 40$ & $7 \cdot 54 \pm 0 \cdot 82$ & $8 \cdot 65 \pm 1 \cdot 15$ & $31 \cdot 37 \pm 3 \cdot 45$ \\
\hline 13AK-PTA & $<0.01$ & NG & $<0.01$ & $\mathrm{NG}$ \\
\hline 13AK-PTA/pJU2 & $3.66 \pm 0.42$ & $10 \cdot 27 \pm 0.95$ & $7 \cdot 77 \pm 0.97$ & $28 \cdot 34 \pm 3 \cdot 05$ \\
\hline IN-ack & $<0.01$ & NG & $1 \cdot 15 \pm 0.02$ & NG \\
\hline IN-pta & $<0.01$ & NG & $<0.01$ & NG \\
\hline
\end{tabular}

*U (mg protein $)^{-1}$ 


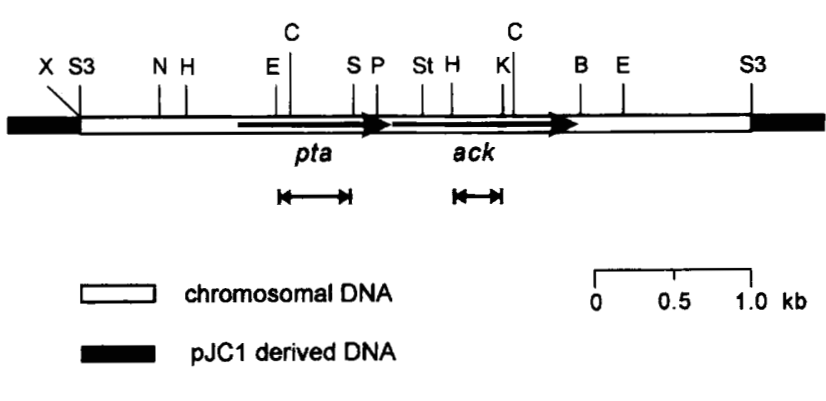

Fig. 1. Restriction map of the Corynebacterium glutamicum chromosomal $4.3 \mathrm{~kb}$ Sau3Al fragment in pJU2. The arrows represent the computer-predicted coding regions of the pta and ack genes. The double-headed arrows indicate the fragments used for the preparation of the Northern hybridization probes. B, BamHI; C, Clal; E, EcoRl; H, HindIII; K, Kpnl; N, Ncil; P, Pstl; S, Sall; S3, Sau3Al; St, Stul; X, Xbal. The $X b a l$ site originates from the cloning site of the vector $p J C 1$.

restriction map of the $4.3 \mathrm{~kb}$ insert from one of the plasmids, pJU2, is shown in Fig. 1.

To confirm the origin of the cloned DNA fragment in pJU2, genomic DNA from Corynebacterium glutamicum was analysed by Southern hybridization. For this purpose, the $1.4 \mathrm{~kb}$ ClaI fragment from pJU2 was isolated, labelled with digoxigenin-dUTP and hybridized to EcoRI-restricted and size-fractionated chromosomal DNA from Corynebacterium glutamicum. The hybridization resulted in a single signal at $2.25 \mathrm{~kb}$ (not shown), which was expected from the restriction map of the pJU2 insert. This result confirms that the isolated DNA fragment corresponds to a fragment within the genome of Corynebacterium glutamicum with no detectable structural alteration.

In a previous study, we isolated fluoroacetate-resistant Corynebacterium glutamicum mutants which were unable to grow on acetate minimal medium and which were defective in either acetate kinase (strain 13AK), phosphotransacetylase (strain 13PTA) or in both enzymes (strain 13AK-PTA) (Wendisch et al., 1997). To confirm that $\mathrm{pJU} 2$ carries the ack gene, pJU2 was tested for its ability to complement the acetate kinase-negative strain Corynebacterium glutamicum $13 \mathrm{AK}$. Considering the fact that in E. coli, S. typhimurium and Methanosarcina thermophila the ack gene is located in the neighbourhood of the phosphotransacetylase gene $p t a$, we also tested pJU2 for its ability to complement the phosphotransacetylase deficiency of strain 13PTA and the deficiency of both enzymes in the double mutant 13AK-PTA. After transformation with pJU2, all three mutants were able to grow on acetate as the sole carbon source. These results suggested that pJU2 not only carried the ack gene but also the pta gene of Corynebacterium glutamicum.

To ensure the presence of the ack and pta genes on the isolated DNA fragment, pJU2 was transformed into Corynebacterium glutamicum WT and the specific enzyme activities of the host and of the transformant, Corynebacterium glutamicum WT/pJU2, were determined (Table 2). After growth on glucose minimal medium, the recombinant strain displayed seven- to tenfold higher specific activities of acetate kinase and phosphotransacetylase than did the host strain or its derivative carrying the cloning vector $\mathrm{pJC} 1$. Since the specific activities of acetate kinase and phosphotransacetylase in the Corynebacterium glutamicum WT were significantly higher when the cells were grown on acetate instead of glucose, it was interesting to study the activities in Corynebacterium glutamicum WT/pJU2 also after growth on acetate. As shown in Table 2, the specific activities of acetate kinase and phosphotransacetylase in Corynebacterium glutamicum WT/pJU2 were still about tenfold higher compared to the host when acetate was used for growth. We also measured the specific acetate kinase and phosphotransacetylase activities in cell-free extracts of the Corynebacterium glutamicum strains 13AK, 13PTA and 13AK-PTA with and without pJU2. As shown in Table 2, pJU2 conferred acetate kinase and phosphotransacetylase activity to all three mutants and the activities of the plasmid-carrying strains were about three- to fourfold higher when the cells were grown on acetate instead of glucose. These results show that the cloned fragment contained functional ack and pta genes including the structures necessary for expression and regulation in Corynebacterium glutamicum.

\section{Nucleotide sequence of the DNA containing the ack and pta genes and amino acid sequence comparisons}

The nucleotide sequence of a 3209 bp Sau3AI-BamHI fragment from $\mathrm{pJU} 2$ was determined from both strands and has been deposited at the EMBL Nucleotide Sequence Database under the accession number X89084. Computer analysis revealed two ORFs extending from bp 1009 to 1995 (ORF1) and from bp 1998 to 3188 (ORF2), the last nucleotide of the TAA stop codon of ORF1 being the first nucleotide of ORF2. Both ORFs exhibited a codon usage corresponding to that of highly expressed corynebacterial genes (Eikmanns, 1992). The amino acid sequences encoded by ORF1 and ORF2 show significant identity to phosphotransacetylases and acetate kinases, respectively, from other organisms (see below). These results indicate that ORF1 represents the pta gene and ORF2 represents the ack gene of Corynebacterium glutamicum. The predicted $p t a$ and ack gene products consist of 329 amino acids with an $M_{\mathrm{r}}$ of 35242 and 397 amino acids with an $M_{\mathrm{r}}$ of 43098 , respectively. To identify a possible terminator downstream of the ack gene, the nucleotide sequence of the $460 \mathrm{bp}$ downstream of ack was determined and included in the sequence deposited at the EMBL database. Centred 34 bp downstream of ack, at positions 3206 to 3246 in the assembled sequence, a region of dyad symmetry followed by several $\mathrm{T}$ residues similar to rho-independent transcription terminators (Rosenberg \& Court, 1979) was found. The mRNA hairpin loop predicted from this sequence has a $\Delta G\left(25^{\circ} \mathrm{C}\right)$ of $-20.8 \mathrm{kcal} \mathrm{mol}^{-1}\left(-87.4 \mathrm{~kJ} \mathrm{~mol}^{-1}\right)$. This result indicates transcriptional termination downstream of the ack gene.

An alignment of the deduced amino acid sequences of 

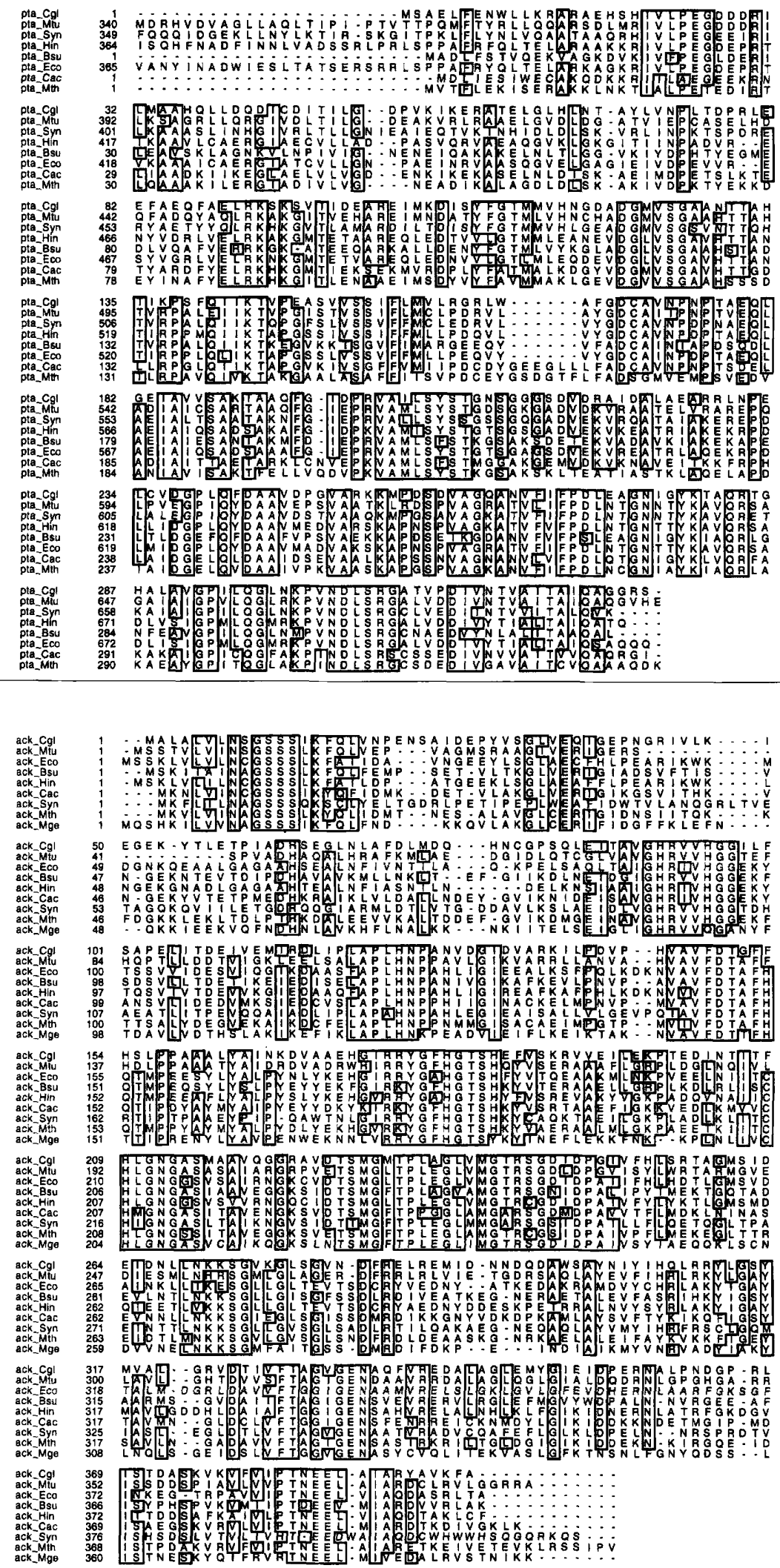

Fig. 2. Multiple amino acid sequence alignment of phosphotransacetylases from different organisms. Identical amino acids are boxed. The aligned sequences are from Corynebacterium glutamicum [pta-Cgl; SWISS-PROT (SP)/swiss-prot-Trembl (SPT) accession no. SPT P77844], Mycobacterium tuberculosis (pta-Mtu; SP P96254), Synechocystis sp. (pta-Ssp; SP P73662), H. influenzae (pta-Hin; SP P45107), B. subtilis (pta-Bsu; SP P39646), E. coli (pta-Eco; SP P39184), Clostridium acetobutylicum (ptaCac; SP P71103) and Methanosarcina thermophila (pta-Mth; SP P38503). The numbers adjacent to species designation refer to the amino acid residue position at the beginning of the line.

\begin{abstract}
Fig. 3. Alignment of the deduced acetate kinase sequences from different organisms. Identical amino acids are boxed. The aligned sequences are from Corynebacterium glutamicum (ack-Cgl; SWISS-PROT accession no. [SP] P77845), Mycobacterium tuberculosis (ack-Mtu; SP P96255), E. coli (ack-Eco; SP P15046), B. subtilis (ack-Bsu; SP P37877), H. influenzae (ack-Hin; SP P44406), Clostridium acetobutylicum (ack-Cac; SP P71104), Synechocystis sp. (ack-Ssp; SP P73162), Methanosarcina thermophila (ptaMth; SP P38502) and Mycoplasma genitalium (ack-Mge; SP P47599) The numbers adjacent to species designation refer to the amino acid residue position at the beginning of the line.
\end{abstract}

the Corynebacterium glutamicum ack and pta gene products with sequences of phosphotransacetylases and acetate kinases from a variety of other bacteria is shown in Figs 2 and 3, respectively. Homology analysis by the method of Myers \& Miller (1988) revealed that the Corynebacterium glutamicum phosphotransacetylase shows a high degree of identity to phosphotransacetylase enzymes (or the carboxy-terminal parts of the respective 
(a)

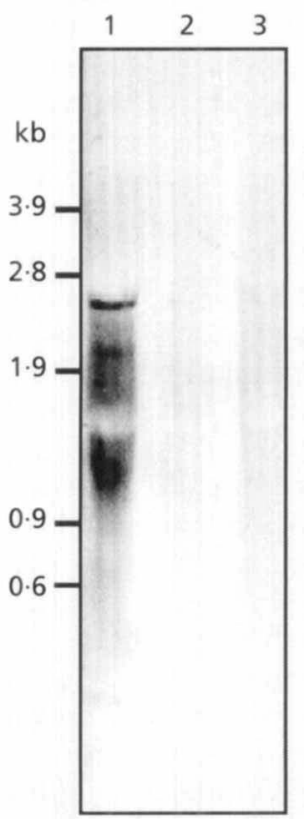

(b)

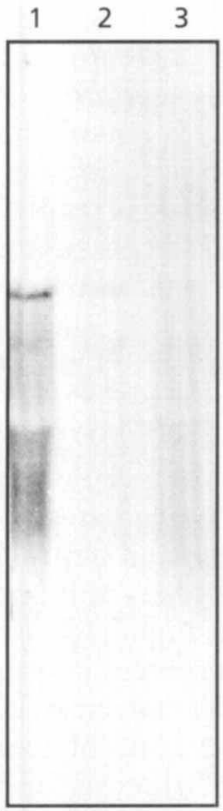

Fig. 4. Northern-blot analysis of the Corynebacterium glutamicum (a) pta (phosphotransacetylase) gene and (b) ack (acetate kinase) gene after growth of the cells on minimal medium containing acetate (lanes 1 and 2) or glucose (lanes 3 ) as a carbon source. Total RNA $(6 \mu \mathrm{g}$ in lanes 1 and $3 ; 0.86 \mu \mathrm{g}$ $(=1 / 7)$ in lanes 2$)$ was electrophoresed and probed with ptaspecific (a) or ack-specific (b) antisense RNA probes. The positions of RNA standards (Gibco-BRL) are shown on the left.

enzymes) from Mycobacterium tuberculosis $(60 \%)$, Synechocystis sp. $(57 \%)$, Haemophilus influenzae $(49 \%)$, B. subtilis $(47 \%)$, E. coli $(47 \%)$, Clostridium acetobutylicum $(44 \%)$ and Methanosarcina thermophila $(42 \%)$. The deduced acetate kinase from Corynebacterium glutamicum showed a relatively high degree of identity to the acetate kinases from Mycobacterium tuberculosis $(53 \%)$, E. coli $(46 \%)$, B. subtilis $(45 \%)$, $H$. influenzae $(45 \%)$, Clostridium acetobutylicum $(42 \%)$, Synechocystis sp. (42\%), Methanosarcina thermophila $(42 \%)$ and Mycoplasma genitalium $(33 \%)$.

\section{Northern-blot analysis of the pta and ack genes and transcriptional fusion experiments}

RNA hybridization experiments were performed to identify the $p t a$ and ack mRNA transcript(s). For this purpose, total RNA from acetate- and from glucosegrown cells of Corynebacterium glutamicum WT was isolated and aliquots were electrophoresed, blotted onto a nylon membrane and hybridized to pta- and ackspecific digoxigenin-labelled antisense RNA probes. Hybridization to both probes resulted in a signal at about $2.5 \mathrm{~kb}$ (Fig. 4), which corresponds approximately to the total size of pta and ack $(1+1 \cdot 2 \mathrm{~kb})$. This result indicates that the $p t a$ and ack genes from Corynebacterium glutamicum form a bicistronic operon. The concentration of the $p t a-a c k$ transcript in acetate-grown cells of Corynebacterium glutamicum was estimated to be four- to sixfold higher than in glucose-grown cells. This difference is slightly higher than the differences observed in the specific activities of acetate kinase and phosphotransacetylase on medium containing either glucose or acetate. However, the results indicate that the observed regulation of the two enzymes occurs primarily at the mRNA level.

To study whether the differences in the level of the pta-ack transcript in acetate- and glucose-grown cells were caused by transcriptional regulation (i.e. promoter control) or by different $p t a-a c k$ mRNA degradation rates, a transcriptional fusion between the pta-ack promoter region and the promoterless cat gene was constructed in the promoter probe vector $\mathrm{pEKplCm}$. The resulting plasmid, pEKplCm-DR2 (carrying the

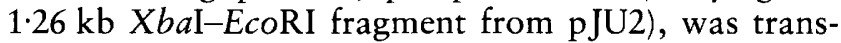
formed into Corynebacterium glutamicum WT and chloramphenicol acetyltransferase activity was determined in the recombinant strains after growth on acetate and glucose minimal medium. Whereas Corynebacterium glutamicum carrying the host vector $\mathrm{pEKplCm}$ showed no chloramphenicol acetyltransferase activity $\left.[<0.01 \mathrm{U} \text { (mg protein })^{-1}\right]$ on either medium, the strain carrying pEKplCm-DR2 showed $0.077 \pm 0.010 \mathrm{U}$ (mg protein $)^{-1}$ during growth on glucose and two- to threefold higher activity $\left[0 \cdot 186 \pm 0.003 \mathrm{U}(\mathrm{mg} \text { protein })^{-1}\right]$ during growth on acetate as the carbon source. The specific phosphotransacetylase and acetate kinase activities in these strains were comparable to those of the WT strain, i.e. also two- to threefold higher when the cells were grown on acetate instead of glucose (data not shown). These results and the results obtained by the Northern-hybridization experiments show that expression of the Corynebacterium glutamicum pta-ack operon is controlled at the transcriptional level and that this regulation is responsible for the different specific activities of phosphotransacetylase and acetate kinase observed in cells grown on acetate or glucose minimal medium.

\section{Inactivation of the chromosomal pta and ack genes in Corynebacterium glutamicum}

To study whether Corynebacterium glutamicum requires the pta and ack genes for growth, the chromosomal copies of both genes were disrupted in Corynebacterium glutamicum WT, resulting in strains IN-ack (ack disrupted) and IN-pta (pta disrupted). The two mutant strains were tested for their phosphotransacetylase and acetate kinase acitivities and for growth on acetate and glucose minimal medium. As shown in Table 2, Corynebacterium glutamicum $\mathrm{IN}$-ack displayed no detectable acetate kinase activity and Corynebacterium glutamicum IN-pta displayed neither phosphotransacetylase nor acetate kinase activity. The lack of both enzyme activities in the latter strain was expected due to the organization of $p t a$ and $a c k$ as an operon. Both mutants were unable to grow on acetate as the sole carbon source, whereas they showed wild-type levels of growth on glucose minimal medium. These results 
strongly indicate that Corynebacterium glutamicum WT possesses only one acetate kinase and one phosphotransacetylase enzyme and they show that the two enzymes are essential for growth of Corynebacterium glutamicum on acetate.

\section{DISCUSSION}

Acetate kinase and phosphotransacetylase genes are known from a variety of different bacteria, e.g. E. coli (Matsuyama et al., 1989, 1994; Kakuda et al., 1994), Methanosarcina thermophila (Latimer \& Ferry, 1993), Mycobacterium tuberculosis (Bergh \& Cole, 1994), Clostridium acetobutylicum (Boynton et al., 1996), $H$. influenzae (Fleischmann et al., 1995), Mycoplasma genitalium (Fraser et al., 1995), Synechocystis sp. (Kaneko et al., 1996) and B. subtilis (Kunst et al., 1997). However, the four latter sequences were identified during genome-sequencing projects solely by sequence similarity, and can therefore not be considered as being well analysed at the molecular level. The present study describes the genetic characterization of acetate kinase and phosphotransacetylase from Corynebacterium glutamicum, physiological effects after disruption of the respective genes, and the biochemical analysis of acetate kinase and phosphotransacetylase in cell-free extracts of this organism.

\section{Chromosomal organization of the ack and pta genes}

Analysis of the Corynebacterium glutamicum acetate kinase and phosphotransacetylase genes revealed they are clustered on the chromosome. Clustering has also been reported for the homologous genes from Mycobacterium tuberculosis (Bergh \& Cole, 1994), Clostridium acetobutylicum (Boynton et al., 1996), E. coli (Kakuda et al., 1994) and Methanosarcina thermophila (Latimer \& Ferry, 1993) whereas the Mycoplasma genitalium and $B$. subtilis ack and pta genes are separated by more than $80 \mathrm{~kb}$ (Fraser et al., 1995; Kunst et al., 1997). The arrangement of ack and pta in Corynebacterium glutamicum is in the same relative order as in Mycobacterium tuberculosis, Methanosarcina thermophila and Clostridium acetobutylicum, with pta located in front of ack (Bergh \& Cole, 1994; Latimer \& Ferry, 1993; Boynton et al., 1996). The opposite arrangement of ack and pta, i.e. ack located in front of pta, was found in E. coli and S. typhimurium (Kwan et al., 1988; Kakuda et al., 1994). Taken together, the data indicate a high degree variation concerning the location and the arrangement of the $a c k$ and $p t a$ genes in different organisms.

\section{Transcriptional organization and regulation of the ack and pta genes}

Northern-blot analysis of total Corynebacterium glutamicum RNA revealed that in Corynebacterium glutamicum the pta and ack genes constitute an operon as has also been shown for the homologous genes from Methanosarcina thermophila, Clostridium acetobutylicum and E. coli (Boynton et al., 1996; Kakuda et al.,
1994; Singh-Wissmann \& Ferry, 1995). Moreover, our Northern analysis and the results of the cat-fusion experiment indicate that the pta-ack operon in Corynebacterium glutamicum is subject to transcriptional regulation. Singh-Wissmann \& Ferry (1995) showed that expression of the Methanosarcina thermophila $p t a-a c k$ operon is regulated by the growth substrate: the steady-state levels of $p t a-a c k$ transcript were severalfold higher in acetate-grown cells than in cells grown on other substrates such as methanol, mono-, di- or trimethylamine. Transcriptional regulation was also shown for the acetate kinase gene from $B$. subtilis (Grundy et al., 1993). However, in this organism the expression of ack is induced in the presence of excess glucose by a mechanism involving the catabolite-control regulator protein CcpA (Grundy et al., 1993). In addtion, B. subtilis ack mutants show unaltered growth on acetate but impaired growth on glucose (Grundy et al., 1993). Therefore, it was suggested that acetate kinase and phosphotransacetylase in B. subtilis are not required for the utilization of acetate but for its formation in the presence of glucose. In E. coli and S. typhimurium the ack-pta operon is constitutively expressed, with only a modest (less than twofold) induction upon anaerobiosis or starvation conditions and there are no indications for induction by acetate (Brown et al., 1977; Kwan et al., 1988; Nyström, 1994; Clark \& Cronan, 1996). This is in agreement with the observations that in E. coli the acetate kinase/phosphotransacetylase pathway operates in both directions and thus serves not only for growth on acetate as carbon source but also for acetate excretion (Huisman et al., 1996) and for energy conservation during anaerobic growth on carbohydrates (Thauer $e t$ $a l ., 1977)$. In the present study, the defined pta and ack mutants of Corynebacterium glutamicum showed no impairment of growth on glucose but were unable to grow on acetate as the sole carbon source. Furthermore, our experiments revealed transcriptional induction of the pta-ack operon from Corynebacterium glutamicum by acetate. These data indicate that the acetate kinase/ phosphotransacetylase pathway in Corynebacterium glutamicum mainly serves for acetate utilization.

\section{Significance of acetate kinase and phosphotransacetylase}

In E. coli, acetate can be activated not only by acetate kinase/phosphotransacetylase but also by acetyl-CoA synthetase, which directly converts acetate to acetylCoA (Brown et al., 1977). While in E. coli the former pathway is required for growth on high concentrations of acetate, the acetyl-CoA synthetase is used when acetate is present at low concentrations (Kumari et al., 1995). Testing of Corynebacterium glutamicum crude extracts for the presence of acetyl-CoA synthetase revealed no enzymic activity (data not shown) as has previously been reported for Corynebacterium glutamicum subsp. flavum (Ozaki \& Shiio, 1969). Although we cannot definitely exclude that Corynebacterium glutamicum possesses an acetyl-CoA synthetase, our results indicate that in Corynebacterium glutamicum 
under our conditions, acetate is primarily activated by the acetate kinase/phosphotransacetylase pathway.

It is interesting to note that Corynebacterium glutamicum showed distinct acetate kinase and phosphotransacetylase activities, even when the cells were grown on glucose as the sole carbon source. One reason for the presence of both enzymes in the absence of acetate might be their requirement for acetate overflow during oxygenlimited growth (Dominguez et al., 1993). Another reason for the background level of acetate kinase and phosphotransacetylase in the absence of acetate might be that in Corynebacterium glutamicum, efficient acetate activation is required for the induction of acetate kinase and phosphotransacetylase and also of the glyoxylate cycle enzymes isocitrate lyase and malate synthase (Wendisch et al., 1997).

\section{Coordinated transcriptional regulation of acetate kinase, phosphotransacetylase, isocitrate lyase and malate synthase}

When Corynebacterium glutamicum grows in the presence of acetate, the cells show higher specific activities of all four key enzymes of acetate metabolism (acetate kinase, phosphotransacetylase, isocitrate lyase and malate synthase) than during growth on other substrates (Reinscheid et al., 1994a, b; Wendisch et al., 1997). In the cases of isocitrate lyase and malate synthase, this regulation has been shown to be exerted at the level of transcription of the respective ace $A$ and $a c e B$ genes (Wendisch et al., 1997). Our findings that acetate kinase and phosphotransacetylase in Corynebacterium glutamicum are also transcriptionally regulated in response to the presence of acetate in the growth medium may suggest that the four key enzymes of acetate metabolism are under common transcriptional control in this organism. Therefore, it can be speculated that a transcriptional regulator acts on the promoters of ace $A$, $a c e B$ and the $p t a-a c k$ operon. However, the induction of the ace $A$ and $a c e B$ genes was much stronger (100- and 50 -fold, respectively) than that of the pta-ack operon (threefold). This might be caused by different affinities of the postulated transcriptional regulator to the respective operator regions of $a c e A, a c e B$ and the pta-ack operon or by differences in the promoter region of the respective genes. Close inspection of the upstream regions of the ace $A, a c e B$ and $p t a$ genes did not reveal a common operator motif and further studies are necessary to unravel the mechanisms and the proteins involved in the transcriptional regulation of the genes encoding the enzymes involved in acetate metabolism of Corynebacterium glutamicum.

\section{Comparison of the phosphotransacetylase and acetate kinase amino acid sequences from Corynebacterium glutamicum with those from other organisms}

Structural analysis of the deduced phosphotransacetylase amino acid sequence from Corynebacterium glutamicum revealed a polypeptide of 329 amino acids with an $M_{\mathrm{r}}$ of 35242 . With this size, the phosphotransacetylase of Corynebacterium glutamicum is comparable to the homologous enzymes from B. subtilis, Clostridium acetobutylicum and Methanosarcina thermophila (Kunst et al., 1997; Boynton et al., 1996; Latimer \& Ferry, 1993), whereas the phosphotransacetylase enzymes deduced from the pta sequences from Mycobacterium tuberculosis, Synechocystis sp., H. influenzae and $E$. coli consist of about 700 residues $\left(M_{\mathrm{r}}\right.$ 75000-80000) (Bergh \& Cole, 1994; Kakuda et al., 1994; Fleischmann et al., 1995; Kaneko et al., 1996). The comparison of the Corynebacterium glutamicum enzyme with other phosphotransacetylases (Fig. 2) revealed a high degree of identity to the 'small' phosphotransacetylases and to the carboxy-terminal 330 amino acids of the 'large' enzymes. Highly conserved sequence motifs were found around two arginine residues $\left(\mathrm{R}^{92}\right.$ and $\mathrm{R}^{308}$ in the Corynebacterium glutamicum sequence) which have been suggested to be essential for enzymic activity or for the binding of CoA in the Methanosarcina thermophila enzyme $\left(\mathrm{R}^{87}\right.$ and $\mathrm{R}^{310}$, respectively, in the Methanosarcina thermophila enzyme) (Rasche et al., 1997).

Amino acid sequence comparison of the deduced acetate kinase from Corynebacterium glutamicum with the respective enzymes from other organisms revealed high levels of similarity with respect to size and primary structure (Fig. 3). Recently, the three-dimensional structure of acetate kinase from Methanosarcina thermophila was elucidated (Buss et al., 1997) and by site-directed mutagenesis, three glutamate residues were found to be essential for catalysis $\left(\mathrm{E}^{384}\right)$ or for substrate binding $\left(\mathrm{E}^{97}\right.$ and $\mathrm{E}^{385}$ ) (Singh-Wissmann et al., 1997). The alignment of all known acetate kinases revealed a $100 \%$ conservation of $\mathrm{E}^{384}$ and $\mathrm{E}^{385}$, emphasizing the relevance of these two residues proposed by Singh-Wissmann et al. (1997).

\section{ACKNOWLEDGEMENTS}

This work was supported by grant BIO4-CT96-0145 within the 4th Framework Programme of the EC. S. Schnicke acknowledges a fellowship from the Hermann-SchlosserStiftung.

\section{REFERENCES}

Aceti, D. J. \& Ferry, J. G. (1988). Purification and characterization of acetate kinase from acetate-grown Methanosarcina thermophila. J Biol Chem 263, 15444-15448.

Bergh, S. \& Cole, S. T. (1994). MycDB: an integrated mycobacterial database. Mol Microbiol 12, 517-534.

Börmann, E. R., Eikmanns, B. J. \& Sahm, H. (1992). Molecular analysis of the Corynebacterium glutamicum gdh gene encoding glutamate dehydrogenase. Mol Microbiol 6, 317-326.

Boynton, Z. L., Bennett, G. N. \& Rudolph, F. B. (1996). Cloning, sequencing, and expression of genes encoding phosphotransacetylase and acetate kinase from Clostridium acetobutylicum ATCC 824. Appl Environ Microbiol 62, 2758-2766.

Brown, T. D. K., Jones-Mortimer, M. C. \& Kornberg, H. L. (1977). 
The enzymatic interconversion of acetate and acetyl-coenzyme A in Escherichia coli. J Gen Microbiol 102, 327-336.

Buss, K. A., Ingram-Smith, C., Ferry, J. G., Sanders, D. A. \& Hasson, M. S. (1997). Crystallization of acetate kinase from Methanosarcina thermophila and prediction of its fold. Protein Sci 6, 2659-2662.

Clark, D. P. \& Cronan, J. E., Jr (1996). Two-carbon compounds and fatty acids as carbon sources. In Escherichia coli and Salmonella typhimurium: Cellular and Molecular Biology, vol. 1, pp. 343-357. Edited by F. C. Neidhardt \& others. Washington, DC: American Society for Microbiology.

Cremer, J., Treptow, C., Eggeling, L. \& Sahm, H. (1988). Regulation of enzymes of lysine biosynthesis in Corynebacterium glutamicum. J Gen Microbiol 134, 3221-3229.

Dominguez, H., Nezondet, C., Lindley, N. D. \& Cocaign, M. (1993). Modified carbon flux during oxygen limited growth of $C$. glutamicum and the consequences for amino acid overproduction. Biotechnol Lett 15, 449-454.

van Dyk, T. K. \& LaRossa, R. A. (1987). Involvement of ack-pta operon products in $\alpha$-ketobutyrate metabolism by Salmonella typhimurium. Mol Gen Genet 207, 435-440.

Eikmanns, B. J. (1992). Identification, sequence analysis, and expression of a Corynebacterium glutamicum gene cluster encoding the three glycolytic enzymes glyceraldehyde-3-phosphate dehydrogenase, 3-phosphoglycerate kinase, and triosephosphate isomerase. J Bacteriol 174, 6076-6086.

Eikmanns, B. J., Kleinertz, E., Liebl, W. \& Sahm, H. (1991a). A family of Corynebacterium glutamicum/Escherichia coli shuttle vectors for cloning, controlled gene expression, and promoter probing. Gene 102, 93-98.

Eikmanns, B. J., Metzger, M., Reinscheid, D., Kircher, M. \& Sahm, H. (1991b). Amplification of three threonine biosynthesis genes in Corynebacterium glutamicum and its influence on carbon flux in different strains. Appl Microbiol Biotechnol 34, 617-622.

Eikmanns, B. J., Thum-Schmitz, N., Eggeling, L., Ludtke, K.-U. \& Sahm, H. (1994). Nucleotide sequence, expression and transcriptional analysis of the Corynebacterium glutamicum gltA gene encoding citrate synthase. Microbiology 140, 1817-1828.

Fleischmann, R. D., Adams, M. D., White, O. \& 37 other authors (1995). Whole-genome random sequencing and assembly of Haemophilus influenzae Rd. Science 269, 496-512.

Fox, D. K. \& Roseman, S. (1986). Isolation and characterization of homogeneous acetate kinase from Salmonella typhimurium and Escherichia coli. J Biol Chem 261, 13487-13497.

Fraser, C. M., Gocayne, J. D., White, O. \& 22 other authors (1995). The minimal gene complement of Mycoplasma genitalium. Science 270, 397-403.

Gornall, A. G., Bardawill, C. J. \& David, M. M. (1949). Determination of serum proteins by means of the biuret reaction. J Biol Chem 177, 751-766.

Grundy, F. J., Waters, D. A., Allen, S. H. G. \& Henkin, T. M. (1993). Regulation of the Bacillus subtilis acetate kinase gene by CcpA. J Bacteriol 175, 7348-7355.

Guest, J. R. (1979). Anaerobic growth of Escherichia coli K12 with fumarate as terminal electron acceptor. Genetic studies with menaquinones and fluoroacetate-resistant mutants. $J$ Gen Microbiol 115, 259-271.

Hanahan, D. (1985). Studies on transformation of Escherichia coli with plasmids. $J \mathrm{Mol} \mathrm{Biol} \mathrm{166,557-580.}$

Huisman, G. W., Siegele, D. A., Zambrano, M. M. \& Kolter, R. (1996). Morphological and physiological changes during stationary phase. In Escherichia coli and Salmonella typhimurium:
Cellular and Molecular Biology, vol. 1, pp. 1672-1682. Edited by F. C. Neidhardt \& others. Washington, DC: American Society for Microbiology.

Kakuda, H., Hosono, K., Shiroishi, K. \& Ichihara, S. (1994). Identification and characterization of the ackA (acetate kinase A)-pta (phosphotransacetylase) operon and complementation analysis of acetate utilization by an ackA-pta deletion mutant of Escherichia coli. J Biochem 116, 916-922.

Kaneko, T., Sato, S., Kotani, H. \& 21 other authors (1996). Sequence analysis of the genome of the unicellular cyanobacterium Synechocystis sp. strain PCC6803. II. Sequence determination of the entire genome and assignment of potential protein-coding regions. DNA Res 3,109-136.

Kinoshita, S. \& Tanaka, K. (1972). Glutamic acid. In The Microbial Production of Amino Acids, pp. 263-324. Edited by K. Yamada. New York: Wiley.

Kornberg, H. L. (1966). Anaplerotic sequences and their role in metabolism. In Essays in Biochemistry, vol. 2, pp. 1-31. Edited by P. N. Campbell \& G. P. Greville. New York: Academic Press.

Kumari, S., Tishel, R., Eisenbach, M. \& Wolfe, A. J. (1995). Cloning, characterization, and fuctional expression of acs, the gene which encodes acetyl coenzyme A synthetase in Escherichia coli. J Bacteriol 177, 2878-2886.

Kunst, F., Ogasawaka, N., Mozer, I. \& 148 other authors (1997). The complete genome sequence of the Gram-positive bacterium Bacillus subtilis. Nature 390, 249-256.

Kwan, H. S., Chui, H. W. \& Wong, K. K. (1988). ack: : Mud1-8 (Ap ${ }^{r}$ lac) operon fusions of Salmonella typhimurium LT2. Mol Gen Genet 211, 183-185.

Latimer, M. \& Ferry, J. G. (1993). Cloning, sequence analysis, and hyperexpression of the genes encoding phosphotransacetylase and acetate kinase from Methanosarcina thermophila.J Bacteriol $175,6822-6829$.

Leuchtenberger, W. (1996). Amino acids - technical production and use. In Biotechnology, vol. 6, pp. 465-502. Edited by H.-J. Rehm, G. Reed, A. Pühler, P. Stadler \& M. Roehr. Weinheim: $\mathrm{VCH}$.

Lundie, L. L. \& Ferry, J. G. (1989). Activation of acetate by Methanosarcina thermophila. J Biol Chem 264, 18392-18396.

Matsuyama, A., Yamamoto, H. \& Nakano, E. (1989). Cloning, expression, and nucleotide sequence of the Escherichia coli $\mathrm{K}-12$ ackA gene. J Bacteriol 171, 577-580.

Matsuyama, A., Yamamoto-Otake, H., Hewitt, J., MacGillivray, R. T. A. \& Nakano, E. (1994). Nucleotide sequence of the phosphotransacetylase gene of Escherichia coli strain K12. Biochim Biophys Acta 1219, 559-562.

Myers, E. W. \& Miller, W. (1988). Optimal alignments in linear space. CABIOS 4, 11-17.

Nesvera, J., Patek, M., Hochmannova, J., Abrhamova, Z., Becvarova, V., Jelinkova, M. \& Vohradsky, J. (1997). Plasmid pGA1 from Corynebacterium glutamicum codes for a gene product that positively influences plasmid copy number. J Bacteriol 179, $1525-1532$.

Nyström, T. (1994). The glucose-starvation stimulon of Escherichia coli: induced and repressed synthesis of enzymes of central metabolic pathways and role of acetyl phosphate in gene expression and starvation survival. Mol Microbiol 12, 833-843.

Ozaki, H. \& Shiio, I. (1969). Regulation of the TCA and glyoxylate cycles in Brevibacterium flavum. J Biochem 66, 297-311.

Rado, T. A. \& Hoch, J. A. (1973). Phosphotransacetylase from Bacillus subtilis: purification and physiological studies. Biochim Biophys Acta 321, 114-125. 
Rasche, M. E., Smith, K. S. \& Ferry, J. G. (1997). Identification of cysteine and arginine residues essential for the phosphotransacetylase from Methanosarcina thermophila. J Bacteriol 179, 7712-7717.

Reinscheid, D. J., Eikmanns, B. J. \& Sahm, H. (1994a). Characterization of the isocitrate lyase gene from Corynebacterium glutamicum and biochemical analysis of the enzyme. J Bacteriol 176, 3474-3483.

Reinscheid, D. J., Eikmanns, B. J. \& Sahm, H. (1994b). Malate synthase from Corynebacterium glutamicum: sequence analysis of the gene and biochemical characterization of the enzyme. Microbiology 140, 3099-3108.

Rosenberg, M. \& Court, D. (1979). Regulatory sequences involved in the promotion and termination of RNA transcription. Annu Rev Genet 13, 319-353.

Sambrook, J., Fritsch, E. F. \& Maniatis, J. (1989). Molecular Cloning: a Laboratory Manual. Cold Spring Harbor, NY: Cold Spring Harbor Laboratory.

Schäfer, A., Kalinowski, J., Simon, R., Seep-Feldhaus, H. \& Puhler, A. (1990). High-frequency conjugal plasmid transfer from Gramnegative E. coli to various Gram-positive coryneform bacteria. $J$ Bacteriol 172, 1663-1666.

Schrumpf, B., Schwarzer, A., Kalinowski, J., Pühler, A., Eggeling, L. \& Sahm, H. (1991). A functionally split pathway for lysine synthesis in Corynebacterium glutamicum. J Bacteriol 173, $4510-4516$.

Schwarzer, A. \& Pühler, A. (1991). Manipulation of Corynebacterium glutamicum by gene disruption and replacement. Bio/Technology 9, 84-87.

Shaw, W. V. (1975). Chloramphenicol acetyltransferase from chloramphenicol-resistant bacteria. Methods Enzymol 43, 737-755.

Shiio, I., Momose, H. \& Oyama, A (1969). Genetic and biochemical studies on bacterial formation of L-glutamate. I. Relationship between isocitrate lyase, acetate kinase, and phosphate acetyl- transferase levels and glutamate production in Brevibacterium flavum. J Gen Appl Microbiol 15, 27-40.

Shimizu, M., Suzuki, T., Kameda, K.-Y. \& Abiko, Y. (1969). Phosphotransacetylase of Escherichia coli $\mathrm{B}$, purification and properties. Biochim Biophys Acta 191, 550-558.

Simon, R., Priefer, U. \& Pühler, A. (1983). A broad host range mobilization system for in vivo genetic engineering: transposon mutagenesis in gram-negative bacteria. Bio/Technology 1, 784 791.

Singh-Wissmann, K. \& Ferry, J. G. (1995). Transcriptional regulation of the phosphotransacetylase-encoding and acetate kinaseencoding genes ( $p t a$ and $a c k$ ) from Methanosarcina thermophila. J Bacteriol 177, 1699-1702.

Singh-Wissmann, K., Ingram-Smith, C., Miles, R. D. \& Ferry, J. G. (1997). Identification of essential glutamates in the acetate kinase from Methanosarcina thermophila. J Bacteriol 180, 1129-1134.

Thauer, R. K., Jungermann, K. \& Decker, K. (1977). Energy conservation in chemotrophic anaerobic bacteria. Bacteriol Rev 41, 100-180.

Vieira, J. \& Messing, J. (1982). The pUC plasmids, an M13mp7derived system for insertion mutagenesis and sequencing with synthetic universal primers. Gene 19, 259-268.

Wendisch, V. E., Spies, M., Reinscheid, D. J., Schnicke, S., Sahm, H. \& Eikmanns, B. J. (1997). Regulation of acetate metabolism in Corynebacterium glutamicum: transcriptional control of the isocitrate lyase and malate synthase genes. Arch Microbiol 168, 262-269.

Winzer, K., Lorenz, K. \& Dürre, P. (1997). Acetate kinase from Clostridium acetobutylicum: a highly specific enzyme that is actively transcribed during acidogenesis and solventogenesis. Microbiology 143, 3279-3286.

Received 24 August 1998; revised 20 October 1998; accepted 28 October 1998. 